\title{
AUTOCHTHONOUS GRANODIORITES NORTH-WEST OF FREDERIKSHÅBS ISBLINK, FISKENESSET REGION
}

\author{
A. M. Hopgood
}

\section{Introduction}

The gneiss complex immediately north-west of Frederikshåbs Isblink is composed mostly of amphibolite facies, grey, streaky, quartzo-feldspathic, biotite and hornblende gneisses. Subordinate amphibolites, hornblendites, thin anorthosites, peridotite lenses up to $200 \mathrm{~m}$ across, rare concordant marble bands and associated calc-silicate gneisses and kyanite and sillimanite gneisses make up the bulk of the remainder, and the whole has been complexly deformed. Occupying the higher ground within the complex, and comprising the largest single lithological unit there is a considerable volume of massive weathering, porphyroblastic granodiorite and granodiorite gneiss. Field relationships show this to be unquestionably autochthonous and almost certainly of palingenetic origin and while on a small scale the 'contact' with the surrounding gneisses may be locally discordant, overall it follows closely the large scale structure and this suggests its control by preexisting lithology.

\section{Field description}

The granodiorites vary in aspect from uniform porphyroblastic rocks to gneisses in which the streaky foliation has become slightly blurred by the strong development of $0.25-0.5 \mathrm{~cm}$ plagioclase porphyroblasts. The first scattered appearance of those in small isolated exposures in the north-east of the area imparts a spotted aspect to the gneisses. These spotted gneisses form a more or less continuous mappable unit. In one instance scattered (almost pegmatoid) development of porphyroblasts as large as $4 \mathrm{~cm}$ across imparts a conglomeratic aspect to the rock over an area of a few hundred square metres within the outcrop of a single isoclinal fold. With reduction in spacing of the spots a grey porphyroblastic gneiss with a faint foliation results which grades into nebulite with relict foliation and folds, thence to a foliated granodiorite, and ultimately to a non-foliated 
homogeneous granodiorite which may contain occasional pods of amphibolite and hornblendite, often as relict fold hinges.

The spotting of the gneisses which heralds the onset of the granitization often results in a rock which is finely rodded and it appears that at times the porphyroblasts have replaced and accentuated existing rodding parallel to the hinges of of early fold structures in the gneiss. This rodding may be either fine (a millimetre or two in diameter) or coarse ( 0.25 to $0.5 \mathrm{~cm}$ across) apparently depending on whether the host gneiss was originally biotitic or hornblendic.

The contact between the granodiorite and the gneiss is seldom sharply transgressive and no cases were seen where it could be regarded as intrusive although intrusive relations were seen farther south (Andersen pers. comm.). Nevertheless the gradation from streaky grey gneiss to foliated granite is at some localities an extremely rapid one. The two distinct rock types lie within a metre or two of one another across a narrow transition zone of nebulite which can be traced without difficulty along the outcrop, although because of the geometry of the folding it may lie more or less perpendicular to the foliation in the streaky gneisses, particularly when this folding is tight with axial surfaces inclined at high angles to the general trend of the foliation.

While mapping tends to show an overall broad concordance of the granodiorite margins with the foliation in the streaky gneisses, suggesting they are confined to one or more similar lithological units, close examination shows that locally transgressive relationships such as that described above often occur on a small scale. It seems that there was a two-fold control over the distribution of the granodiorite. Besides that imposed by the special physical conditions, the structural control by the lithology most susceptible to palingenesis was important.

However, in places where the intensity of palingenesis was greatest, less susceptible rocks were also granitised to the extend that lithological boundaries were transgressed at least to a limited local extent to produce discordance between the granodiorite contact and the gneiss foliation. Amphibolite and hornblendite have resisted the effects of palingenesis, even when this has been extreme, since relics the same as those seen in the streaky gneisses can still be seen parallel to the original foliation direction. Nevertheless they are rare throughout the granodiorite, indicating that the original gneisses from which the granodiorites were derived must have been of a type initially deficient in these mafic rock types.

There is no obvious field evidence of significant mobility of the granodiorite and as far as can be ascertained, the amphibolite xenoliths which appear to be relics from an earlier episode of migmatisation have not been disorientated by flow. This can be seen in the case of folds which still retain attitudes consistent with those of the same generation in adjacent areas that have been little affected by palingenesis. 


\section{Petrography}

In hand specimen and in terms of field occurrence, but not texturally, the granodiorites appear to have some similarities to those described from the nunataks and semi-nunataks of Frederikshåbs Isblink by Dawes (1970). In the field, the gradational contacts and nebulitic boundaries and foliated granites are similar to those noted by Dawes, although he describes as the "most common type" a rock which is more or less equigranular, displaying a slight foliation whereas only "some" porphyroblastic types occur and in these porphyroblasts may reach 3 $\mathrm{cm}$ in length, compared with the typically $0.5 \mathrm{~cm}$ diameter porphyroblast of the granodiorite under discussion here.

The foliation in the streaky gneisses close to the granodiorite is marked by alternation of darker bands rich in biotite (or hornblende) with bands deficient in mafic minerals. Nearer the granodiorites the integrity of the darker bands is lost and they finally disappear in the homogeneous granodiorites, the more biotitic gneisses tending to preserve their foliation later into the granodiorite.

Thin section examination confirms the relative simplicity of the mineralogy and shows that the rocks are conspicuously poor in potash feldspar. The leucocratic minerals consist of strained quartz with sutured margins, fresh plagioclase clumps and porphyroblasts (oligoclase/albite) displaying ubiquitous albite and pericline twinning and sometimes containing minute amounts of antiperthitic potash feldspar in the central parts. There is some slight sericitisation. Overall, potash feldspar is insignificant in amount and there are only a few very small patches of interstitial microcline visible in the thin sections. A few scattered shreds of muscovite, small patches of carbonate, scattered grains of zircon and irregular fragments of euhedral apatite make up the remainder of the light minerals. The only mafic mineral of any importance is green-brown biotite in flakes and shreds, rarely with pleochroic haloes around minute zircons, and this by its alignment in bands accounts for the foliation in the least granitised rocks. In addition there is a small amount of accessory epidote in small, pale brown granules. The minerals are all clear and fresh with very little evidence of later alteration, except where incipient fracturing has promoted sericitisation of the plagioclase feldspars. Allanite, although noted from the nunatak granites by Dawes (1970) and locally abundant in the streaky gneiss in this field, was not seen in thin sections of the granodiorite.

\section{Texture}

Although in hand specimen there appears to be some alignment of porphyroblasts parallel to the subvertical axial planes of later $\left(\mathrm{F}_{\overline{5}}\right)$ folds, in thin section and under the hand lens the granodiorites appear to be typically autochthonous post- 
tectonic rocks. They are porphyroblastic and only rarely possess a granoblastic texture, even where palingenesis has been extreme.

With a hand lens and in thin section it is possible to trace the effects on the foliation of the progressive development of the porphyroblasts formed in biotite gneisses. Disruption of the foliation by porphyroblast growth begins when the continuity of the biotite bands is interrupted with the disorientation around the porphyroblasts of the biotite flakes. With increasing porphyroblast development the biotites cluster in random orientation around the porphyroblasts so that the foliation is ultimately destroyed completely in the homogeneous granodiorites. Apart from the fact that biotite flakes appear to have been slightly displaced to a very limited extent by porphyroblast growth, there is no indication in thin section that a fluid state was ever reached.

Comparison of the mineralogy of the streaky gneiss and that of the granodiorite suggests that metasomatism was unimportant and that the granodiorites are purely palingenetic, but confirmation of this would depend on chemical anlyses. An interesting feature of some of the streaky gneiss plagioclases is the presence of slight faint concentric zoning which might suggest a magmatic origin for them. The earlier history of the gneisses may have a bearing on this since they are essentially migmatitic and were therefore at some stage in or close to a magmatic state. Certainly field relations and thin section examination shows conclusively the granodiorites to be autochthonous rather than igneous in origin.

\section{Relative time of granitisation}

Field evidence supported by thin section analysis of orientated specimens has shown that the palingenesis took place after the gneisses had been deformed by at least four episodes of folding. Both primary gneissic foliation, and secondary foliation developed parallel to the axial planes of asymmetrical folds, can be seen to be gradually obliterated by the palingenesis. The latest folds recognised as having been effected by the palingenesis are those ascribed to the fourth fold generation in the gneiss. These, like the third generation, are asymmetrical and inclined. Relict amphibolite folds belonging to this generation can be seen suspended apparently without disorientation within the products of extreme palingenesis in a number of locations, and in a few instances exceptionally good exposures display the relationships of asymmetrical folds and their associated axial planar structure in the streaky gneiss to the granitisation. Here it is possible to see the gradual blurring and ultimate obliteration of the axial planar structure, apart from occasional aligned discontinuous lenses representing relict quartzo-feldspathic veins originally emplaced contemporaneously or penecontemporaneously parallel to the axial surfaces. It is thus possible to ascribe a maximum relative age to the palingenesis in the area. No cases were seen of folds of the fourth generation affecting 
the granitized gneisses but in some instances a faint steep to vertical lineation, parallel to easterly trending axial planes related to the fifth recognised generation of folding, indicates that palingenesis took place prior to this episode of folding. Thin sections show traces of fine dusty inclusions in the porphyroblasts and some shattering and granulation parallel to the same direction, thus confirming the age relationship seen in the field.

The last surviving original features in the granodiorite tend to be quartzofeldspathic veins emplaced during earlier migmatisation and these appear to have existed intact with the same orientation until a very late stage was reached in the palingenesis. A similar effect has been seen in granitised biotite gneisses in Western Australia at Lake Dumbleyung. Some of the veins in the granodiorite contain muscovite booklets apparently developed in the late stages of palingenesis and determination of the isotopic age of the mica should serve to place an upper age limit to the palingenesis. Rectilinear quartzo-feldspathic veins and veins of white and smokey quartz cutting the granodiorite appear to be related to the latest episodes of folding in the area.

Comparison of the streaky gneiss and the granodiorite in thin section shows that there is little if any increase in potash feldspar in the granodiorites and suggests that there may not have been significant mobility of alkalis during the granitisation.

\section{Reference}

Dawes, P. R. 1970: Bedrock geology of the nunataks and semi-nunataks in the Frederikshåbs Isblink area of southern West Greenland. Rapp. Grønlands geol. Unders. 29. 